\title{
Alendronate Functionalized Mesoporous Bioactive Glass Nanospheres
}

\author{
Elisa Boanini ${ }^{1, *}$, Silvia Panseri ${ }^{2}$, Fabiola Arroyo ${ }^{3}$, Monica Montesi ${ }^{2}$, Katia Rubini ${ }^{1}$, \\ Anna Tampieri ${ }^{2}$, Cristian Covarrubias ${ }^{3}$ and Adriana Bigi ${ }^{1}$ \\ 1 Department of Chemistry “G. Ciamician”, University of Bologna, Via Selmi 2, Bologna 40126, Italy; \\ katia.rubini@unibo.it (K.R.); adriana.bigi@unibo.it (A.B.) \\ 2 Institute of Science and Technology for Ceramics, National Research Council of Italy, Via Granarolo 64, \\ Faenza 48018, Italy; silvia.panseri@istec.cnr.it (S.P.); monica.montesi@istec.cnr.it (M.M.); \\ anna.tampieri@istec.cnr.it (A.T.) \\ 3 Laboratory of Nanobiomaterials, Institute for Research in Dental Sciences, Faculty of Dentistry, University of \\ Chile, Santiago 8380492, Chile; fabiola.arroyo@gmail.com (F.A.); ccovarrubias@odontologia.uchile.cl (C.C.) \\ * Correspondence: elisa.boanini@unibo.it; Tel.: +39-051-209-9548
}

Academic Editor: Gigliola Lusvardi

Received: 21 December 2015; Accepted: 18 February 2016; Published: 26 February 2016

\begin{abstract}
In this work we synthesized mesoporous bioactive glass nanospheres (nMBG) with the aim to utilize them as substrates for loading one of the most potent amino-bisphosphonates, alendronate (AL). The results of the chemical and structural characterization show that the NMBG display a relatively high surface area $\left(528 \mathrm{~m}^{2} / \mathrm{g}\right)$ and a mean pore volume of $0.63 \mathrm{~cm}^{3} / \mathrm{g}$, both of which decrease on increasing alendronate content. It is possible to modulate the amount of AL loaded into the nanospheres up to a maximum value of about $17 \mathrm{wt} \%$. In vitro tests were performed using a human osteosarcoma cell line (MG63) and a murine monocyte/macrophage cell line as osteoclast model (RAW 264.7). The results indicate that even the lower concentration of alendronate provokes decreased tumor cell viability, and that osteoclast activity exhibits an alendronate dose-dependent inhibition. The data suggest that nMBG can act as a suitable support for the local delivery of alendronate, and that the antiresorptive and antitumor properties of the functionalized mesoporous nanospheres can be modulated by varying the amount of alendronate loading.
\end{abstract}

Keywords: mesoporous; bioactive glass nanospheres; alendronate; osteoclast inhibition; anti-cancer

\section{Introduction}

Osteosarcoma (OS) is the most common primary malignant bone tumor in children and adolescents, with a second peak in incidence in adults over the age of 50 [1]. The mainstay of curative osteosarcoma treatment is surgery (often amputation). However, the survival of patients with OS treated with surgery alone is less than $20 \%$ [2]. The basis for the aggressiveness of this tumor is largely unknown. However, although little is known on the mechanisms by which OS destroys the hard matrix of the skeleton, the role of osteoclasts, primary cells involved in bone matrix solubilization, seems to be fundamental in the cancer progression. In detail, recent findings have shown that the induction of osteoclast activity by tumor cells is particularly increased in those patients with aggressive OS $[3,4]$. Recent studies in in vivo models indicate that bisphosphonates (BPs) can inhibit the tumor local expansion and the formation of metastases [5]. In fact, BPs, which are extensively employed for the management of specific disorders of bone metabolism characterized by abnormally increased bone mass resorption, display also antitumor and anti-angiogenetic properties [6-8]. BPs derive chemically 
from pyrophosphates and are characterized by a backbone structure of $\mathrm{P}-\mathrm{C}-\mathrm{P}$ where $\mathrm{P}$ is a phosphonate group. Individual BPs differ in the two covalently bound side chains, $R_{1}$ and $R_{2}$, which complete the tetra valence of the carbon atom. The affinity for the mineral phase of bone is enhanced when $R_{1}$ is an hydroxyl group, whereas the presence of a nitrogen atom in the $\mathrm{R}_{2}$ side chain positively influences the anti-resorptive potency of BPs. Amino BPs (N-BPs), such as alendronate (AL), inhibit farnesyl pyrophosphate (FPP) synthase, a major enzyme in the mevalonate pathway, and, as a consequence, hinder most osteoclast activities [9]. Although clinical studies have reported successful results of long-term uses of N-BPs [10], a vast number of adverse side effects, including osteonecrosis of the jaw and increased risk of subtrochanteric fractures, have been reported [11-13]. These drawbacks have stimulated the development of strategies for alternative administration of BPs, such as local release at specific bone sites [14]. Most of these studies have been performed using calcium phosphates as substrates onto which BPs are loaded through chemisorption from solution or incorporated through direct synthesis [15-23]. Moreover, a few studies have explored the possibility of using siliceous ordered mesoporous materials for controlled delivery of BPs [24,25].

Pure silica materials such as MCM-41 and SBA-15 with ordered mesoporous structure and high surface area have been also studied as matrices for alendronate adsorption and release [24]. Ordered mesoporous materials with $\mathrm{CaO}-\mathrm{SiO}_{2}-\mathrm{P}_{2} \mathrm{O}_{5}$ bioactive glass (BG) composition can be also prepared [26]. BG is an osteoconductive and osteostimulative material able to bond closely with the host bone tissue through the formation of an apatite layer. In addition BG stimulates osteoblast proliferation and differentiation by enhancing the expression of potent osteoblast mitogenic growth factors [27]. Microsized BG particles with SBA-15 type structure (MBG) can be produced by the sol-gel technique. More recently, the synthesis of MBG nanospheres (nMBG) with particle size in the 50-100 nm range, having high surface area and mesoporous volume has been also reported [28]. The incorporation of AL into $\mathrm{NMBG}$ could produce a system that couples AL delivery with the properties of the nanodimensional BG material.

In this study we prepared nano-sized bioactive glass nanospheres (nMBG) loaded with increasing amounts of alendronate. The combined capability of the developed drug system as inhibitor on cancer cells viability and as inhibitor of bone resorption was investigated in vitro through determination of tumor cell proliferation/survival, and osteoclast activity.

\section{Materials and Methods}

\subsection{Preparation and Characterization of Mesoporous Bioactive Glass Nanospheres}

nMBG were synthesized by a hydrothermal method [28] using cetyltrimethylammonium bromide (CTAB) and poly(vinylpyrrolidone) (PVP) as co-templates. In a typical experiment, $1 \mathrm{~g}$ PVP and $0.46 \mathrm{~g} \mathrm{NaOH}$ were first dissolved in $120 \mathrm{~mL}$ distilled water. Then, $1.4 \mathrm{~g}$ CTAB was added to the $\mathrm{PVP}-\mathrm{NaOH}$ solution and stirred for $1 \mathrm{~h}$. Then, tetrahydrate calcium nitrate $\left(\mathrm{Ca}\left(\mathrm{NO}_{3}\right)_{2} \cdot 4 \mathrm{H}_{2} \mathrm{O}\right)$, tetraethyl orthosilicate (TEOS) and triethyl phosphate (TEP) were added with vigorous stirring. The molar ratio of Ca:P:Si was 15:5:80. After stirring for $24 \mathrm{~h}$, the milk-like mixture was sealed in Teflon-lined autoclaves at $80^{\circ} \mathrm{C}$ for $48 \mathrm{~h}$. The products were collected by centrifugation and washed by water and ethanol, 3 times with each. Then the collected powders were dried at $80^{\circ} \mathrm{C}$ overnight and calcined at $550{ }^{\circ} \mathrm{C}$ for $5 \mathrm{~h}$ to remove any remaining PVP and CTAB.

Loading of alendronate on $\mathrm{nMBG}$ was carried out in MilliQ water at different concentrations of sodium alendronate trihydrate $\left(\mathrm{C}_{4} \mathrm{H}_{12} \mathrm{NaNO}_{7} \mathrm{P}_{2} \cdot 3 \mathrm{H}_{2} \mathrm{O}: 0.25,0.5,1 \mathrm{mg} / \mathrm{mL}\right)$. Samples were labelled as AL25, AL50 and AL100, respectively. The reaction was performed on $500 \mathrm{mg} \mathrm{nMBG} / 100 \mathrm{~mL}$ solution at $37^{\circ} \mathrm{C}$, under stirring for $24 \mathrm{~h}$. Then, the products were centrifuged at 10,000 rpm for $30 \mathrm{~min}$, repeatedly washed with double distilled water and dried at $37^{\circ} \mathrm{C}$.

Alendronate content was determined spectrophotometrically via complex formation with $\mathrm{Fe}(\mathrm{III})$ ions [29] in the aqueous solution isolated after centrifugation. A Varian Cary50Bio instrument $(\lambda=290 \mathrm{~nm})$ was used. 
Attenuated total reflectance with Fourier transform infrared spectroscopy (ATR-FTIR) was carried out on an Agilent Cary 630 ATR-FTIR spectrometer (Agilent, Santa Clara, CA, USA).

Thermogravimetric analysis was carried out using a Perkin-Elmer TGA-7 (Perkin Elmer, Monza, Italy). Heating was performed in a platinum crucible in air flow $\left(20 \mathrm{~cm}^{3} / \mathrm{min}\right)$ at a rate of $10^{\circ} \mathrm{C} / \mathrm{min}$ up to $800{ }^{\circ} \mathrm{C}$. The samples weights were in the range $5-10 \mathrm{mg}$.

For transmission electron microscopy (TEM) investigations, dry samples were suspended in ethanol after sonication, and then were transferred onto holey carbon foils supported on conventional copper microgrids. A Philips CM100 transmission electron microscope (Philips, Leiden, The Netherlands), operating at $80 \mathrm{kV}$ was used.

X-ray diffraction (XRD) analysis was carried out by means of a PANalytical X'Pert PRO powder diffractometer (PANalytical, Almelo, The Netherlands) equipped with a fast $X^{\prime}$ Celerator detector. $\mathrm{CuK} \alpha$ radiation was used $(40 \mathrm{~mA}, 40 \mathrm{kV})$. For phase identification the $2 \theta$ range was investigated from 10 to $60,2 \theta$ degrees with a step size of $0.1^{\circ}$ and time/step of $100 \mathrm{~s}$.

Textural characterization of materials was carried out by $\mathrm{N}_{2}$ adsorption at $77 \mathrm{~K}$ in a Micromeritics ASAP 2010 sorptometer (Micrometrics, Norcross, Georgia). The specific surface areas (SSA) were obtained using the Brunauer-Emmett-Teller (BET) method. Pore diameter was estimated from the pore size distribution curves obtained by the Barrett-Joyner-Halenda model.

\subsection{Preparation and Characterization of Disk-Shaped Samples}

In vitro tests were performed on disk-shaped samples $(\varnothing=6.0 \mathrm{~mm})$. Each disk was prepared by pressing $30 \mathrm{mg}$ of powder into cylindrical molds by using a standard evacuable pellet die (Hellma, Mühlheim, Germany), and sterilized using gamma rays (Cobalt-60) at a dose of $25 \mathrm{kGy}$.

Static contact angle measurements were performed on disk-shaped samples. A KSV CAM101 instrument (Nordtest srl, GI, Serravalle Scrivia, Italy) was used under ambient conditions for recording the side profiles of deionized water drops for image analysis. The shape of the drop was recorded in a time range of $0-30 \mathrm{~s}$, by collecting an image every $0.033 \mathrm{~s}$. At least three drops were observed for each sample.

For atomic force microscopy (AFM) imaging a Veeco Nanoscope 3D instrument (Veeco, Oyster Bay, NY, USA) was used. The samples were analyzed in tapping mode using an E scanner (maximum scan size $15 \mu \mathrm{m}$ ) and phosphorus (n) doped silicon probes (spring constant $20-80 \mathrm{~N} / \mathrm{m}$; resonance frequency $250-290 \mathrm{kHz}$; nominal tip radius $<10 \mathrm{~nm}$ ). Roughness parameters, namely arithmetic mean roughness $\left(R_{\mathrm{a}}\right)$, root-square roughness $\left(R_{\mathrm{q}}\right)$, and the vertical distance between the highest and lowest points within the evaluation length $\left(R_{\mathrm{t}}\right)$, were recorded.

Mineralization tests on disk-shaped samples were performed in modified simulated body fluid solution (1.5 SBF). The modified SBF was prepared by dissolving reagent grade $\mathrm{NaCl}, \mathrm{KCl}, \mathrm{NaHCO}_{3}$, $\mathrm{KHCO}_{3}, \mathrm{Na}_{2} \mathrm{HPO}_{4} \cdot 12 \mathrm{H}_{2} \mathrm{O}, \mathrm{MgSO}_{4} \cdot 7 \mathrm{H}_{2} \mathrm{O}, \mathrm{MgCl}_{2} \cdot 6 \mathrm{H}_{2} \mathrm{O}$, and $\mathrm{CaCl}_{2} \cdot 12 \mathrm{H}_{2} \mathrm{O}$ into double-distilled water and buffering at $\mathrm{pH} 7.4$ with Hepes (2-[4-(2-hydroxyethyl)piperazin-1-yl]ethanesulfonic acid) and $\mathrm{NaOH}$ [30] Each disk-shaped sample was incubated in $25 \mathrm{~mL}$ of $1.5 \mathrm{SBF}$ solution at $37^{\circ} \mathrm{C}$ for up to 7 days. Afterwards, samples were abundantly rinsed with distilled water and dried at $37^{\circ} \mathrm{C}$.

Morphological investigations of the samples before and after exposure to SBF solution were performed using a Philips XL-20 scanning electron microscope (Philips) operating at $15 \mathrm{kV}$. The samples were sputter coated with gold before examination. Energy dispersive X-ray analysis (EDX, Philips) analyses were carried out on uncoated specimens.

\subsection{In Vitro Study}

\subsubsection{Cell Cultures}

Human Osteosarcoma cell line, MG63, purchased from Lonza (Basel, Switzerland) were cultured in Dulbecco modified Eagle's medium (DMEM)/F12 Medium (Gibco, Billings, MT, USA), containing $1 \%$ penicillin-streptomycin $(100 \mathrm{U} / \mathrm{mL}-100 \mu \mathrm{g} / \mathrm{mL})$ supplemented with $10 \%$ fetal bovine serum (FBS) 
and kept at $37{ }^{\circ} \mathrm{C}$ in an atmosphere of $5 \% \mathrm{CO}_{2}$. Samples were placed one per well in a 24-well plate and a drop of $20 \mu \mathrm{L}$ containing $1.00 \times 10^{3}$ cells $\left(2.5 \times 10^{3} \mathrm{cells} / \mathrm{cm}^{2}\right)$ was seeded on the center of the upper sample surface allowing cell attachment for $30 \mathrm{~min}$ in the incubator, before addition into each well of $1.0 \mathrm{~mL}$ of cell culture medium.

Murine monocyte/macrophage cell line RAW 264.7, obtained from ATCC cell bank (Manassas, VA, USA), was used as model of osteoclastogenesis [31,32]. RAW 264.7 cells were cultured in DMEM high glucose (Gibco), 10\% FBS and 1\% penicillin-streptomycin (100 U/mL-100 $\mu \mathrm{g} / \mathrm{mL}$ ). RAW 264.7 cells at a concentration of $1.5 \times 10^{3}$ cells $/ \mathrm{cm}^{2}$ were seeded in $0.4 \mu \mathrm{m}$ pore size 24 -well inserts (Merck Millipore, Darmstadt, Germany), and the samples were placed one per well in the 24-well plate. To initiate osteoclasts (OCLs) differentiation, $25 \mathrm{ng} / \mathrm{mL}$ soluble Receptor Activator for Nuclear Factor $\mathrm{kB}$ Ligand (sRANKL, Sigma-Aldrich, St Louis, MO, USA) was added to the culture.

All cell-handling procedures were performed in a sterile laminar flow hood. All cell-culture incubation steps were performed at $37^{\circ} \mathrm{C}$ with $5 \% \mathrm{CO}_{2}$.

\subsubsection{Cell Viability Assay}

MTT reagent (3-(4,5-dimethylthiazol-2-yl)-2,5-diphenyltetrazolium bromide) (Invitrogen, Carlsbad, CA, USA) was prepared at $5 \mathrm{mg} / \mathrm{mL}$ in $1 \times$ PBS. Samples seeded with MG63 cells were incubated with the MTT reagent $1: 10$ for $2 \mathrm{~h}$ at $37^{\circ} \mathrm{C}$. Medium was discarded and cells incubated with $200 \mu \mathrm{L}$ of dimethyl sulfoxide for $15 \mathrm{~min}$. In this assay, the metabolically active cells react with the tetrazolium salt in the MTT reagent to produce a formazan dye that can be observed at $\lambda_{\max }=570 \mathrm{~nm}$, using a Multiskan FC Microplate Photometer (Thermo Fisher Scientific Inc., Waltham, MA, USA) [33]. This absorbance is directly proportional to the number of metabolically active cells. Mean values of absorbance were determined. Three samples per time point per group (day 1,3, and 7) were analyzed.

\subsubsection{Actin Filament Staining}

Actin filament staining was performed to assess osteoclastogenesis. In detail RAW 264.7 cells, grown in 24-well inserts, of nMBG group were washed with phosphate buffered saline (PBS $1 \times$ ) for $5 \mathrm{~min}$, fixed with $4 \%(w / v)$ paraformaldehyde for $15 \mathrm{~min}$ and washed with PBS $1 \times$ for $5 \mathrm{~min}$. Permeabilization was performed with $1 \times$ PBS with $0.1 \%(v / v)$ Triton X-100 for 5 min. Fluorescein isothiocyanate (FITC) conjugated Phalloidin (Invitrogen) $38 \mathrm{nM}$ in $1 \times$ PBS was added for $20 \mathrm{~min}$ at room temperature in the dark [34]. Cells were washed with $1 \times$ PBS for $5 \mathrm{~min}$ and incubated with nuclear stain 4',6-diamidino-2-phenylindole (DAPI) (300 nM, Invitrogen) in 1× PBS for $5 \mathrm{~min}$.

At each time point, one sample per group with MG63 seeded was fixed with $4 \%(w / v)$ paraformaldehyde for $15 \mathrm{~min}$, and cell nuclei were stained with DAPI. Images were acquired by an Inverted Ti-E fluorescence microscope (Nikon Corporation, Tokyo, Japan).

\subsubsection{TRAP Activity Evaluation}

Tartrate resistant acid phosphatase (TRAP), highly expressed by osteoclasts, was measured according to established protocol [35]. Briefly cells, grown in 24-well inserts, were lysed in $1 \mathrm{M}$ $\mathrm{NaCl}$ with $0.2 \%$ Triton X-100. Lysate was incubated with $50 \mathrm{~mL}$ of $5 \mathrm{mM} p$-nitrophenyl phosphate (Sigma-Aldrich, St. Louis, MO, USA) in $25 \mathrm{mM}$ Na-acetate $/ 20 \mathrm{mM}$ Natartrate, $\mathrm{pH} 4.8$ at $37^{\circ} \mathrm{C}$ for $30 \mathrm{~min}$. The reaction was stopped by adding $0.5 \mathrm{M} \mathrm{NaOH}$. Then $100 \mu \mathrm{L}$ of the resulting supernatant was transferred into a 96-well plate, and read by a plate reader at $405 \mathrm{~nm}$. Three samples per time point per group (day 3 and 7) were analyzed. The data were reported as the percentage of the enzymatic activity with respect to the $\mathrm{nMBG}$ group.

\subsubsection{Quantitative Real-Time Polymerase Chain Reaction (qPCR)}

At day 7, RAW 264.7 cells grown in $0.4 \mu \mathrm{m}$ pore size 24-well inserts with the samples placed one per well in the 24-well plate were lysed and total RNA extraction was performed by use of Tri Reagent, followed by the Purelink RNA Mini kit according to the manufacturer's instructions. 
nMBG group was used as control. RNA integrity was analyzed by native agarose gel electrophoresis and quantification performed by the Qubit ${ }^{\circledR} 2.0$ Fluorometer (Invitrogen) together with the Qubit ${ }^{\circledR}$ RNA BR assay kit, following the manufacturer's instructions. Total RNA (500 ng) was reverse transcribed to cDNA using the High-Capacity cDNA Reverse Transcription Kit, according to the manufacturer's instructions. Quantification of gene expression for Catepsin K (CtsK, Mm00484039), Osteoclast-associated immunoglobulin-like receptor (Oscar, Mm00558665), and the housekeeping gene glyceraldehyde 3-phosphate dehydrogenase (GAPDH, Mm99999915) (Life Technologies, Carlsbad, CA, USA) was performed with the StepOne ${ }^{\mathrm{TM}}$ Real-Time PCR System (Applied Biosystems, Foster City, CA, USA). Experiment was done in triplicate, using three technical replicates for each experiment. Data was collected using the OneStep Software (version 2.2.2, Applied Biosystems) and relative quantification was performed using the comparative threshold $\left(C_{t}\right)$ method $\left(\Delta \Delta C_{t}\right)$, where relative gene expression level equals $2^{-\Delta \Delta C_{t}}$ [36].

\subsubsection{Statistical Analysis}

Results were expressed as Mean \pm SEM (standard error mean) plotted on a graph. MTT results analysis was made by two-way analysis of variance, followed by Bonferroni's post-hoc test. Gene expression profiling was analyzed by one-way ANOVA, followed by “Tukey's Multiple Comparison Test". Statistical analysis was performed by the GraphPad Prism software (version 5.0, La Jolla, CA, USA), with statistical significance set at $p \leqslant 0.05$.

\section{Results and Discussion}

\subsection{Chemical and Structural Characterization}

The as-prepared nanospheres (nMBG) exhibit a spherical morphology (Figure 1a) and a size distribution between 50 and $150 \mathrm{~nm}$ (Figure 1b). The high magnification TEM image reported in Figure 1c reveals the internal mesoporous structure of the nanospheres. In agreement, the results of porosity investigation indicate that the $\mathrm{nMBG}$ display a relatively high surface area $\left(528 \mathrm{~m}^{2} / \mathrm{g}\right)$ and a mean pore volume of $0.63 \mathrm{~cm}^{3} / \mathrm{g}$ (Table 1 ).

nMBG nanospheres display a very high loading efficiency of alendronate. Loading was performed through immersion in solutions at different AL concentration up to $1 \mathrm{mg} / \mathrm{mL}$. The results of the spectrophotometric analysis of the AL chromophoric complex with FeIII ions [29] indicate that the amount of AL loaded into the nanospheres increases as the bisphosphonate concentration increases up to about $17 \mathrm{wt} \%$ (Table 1). This value represents the maximum amount of AL that can be adsorbed into the nanoparticles, since immersion in solutions at greater concentration than $1 \mathrm{mg} / \mathrm{mL}$ did not yield greater incorporation. Comparison with the amount of AL present in solution indicates that the efficiency of AL loading is about $100 \%$, independent of concentration. Total calcium content in the nanospheres is about $20 \mathrm{wt} \%$ determined through energy dispersive X-ray analysis (EDX). No significant variation can be appreciated after AL loading.

The increase of the amount of AL incorporated into the nanospheres can be followed also by thermogravimetric analysis. The comparison between the thermogram of nMBG and those of AL loaded nanospheres is reported in Figure 2 and shows increasing total weight loss with increasing AL concentration.

The presence of AL can be also detected by FTIR analysis (Figure 3) by the appearance of an absorption band around $960 \mathrm{~cm}^{-1}$, which can be attributed to the $\mathrm{P}-\mathrm{O}$ bending vibrations of the AL structure 1088-920 $\mathrm{cm}^{-1}$, normally observed in the $1120-950 \mathrm{~cm}^{-1}$ range for organo-phosphorous compounds [37]. 

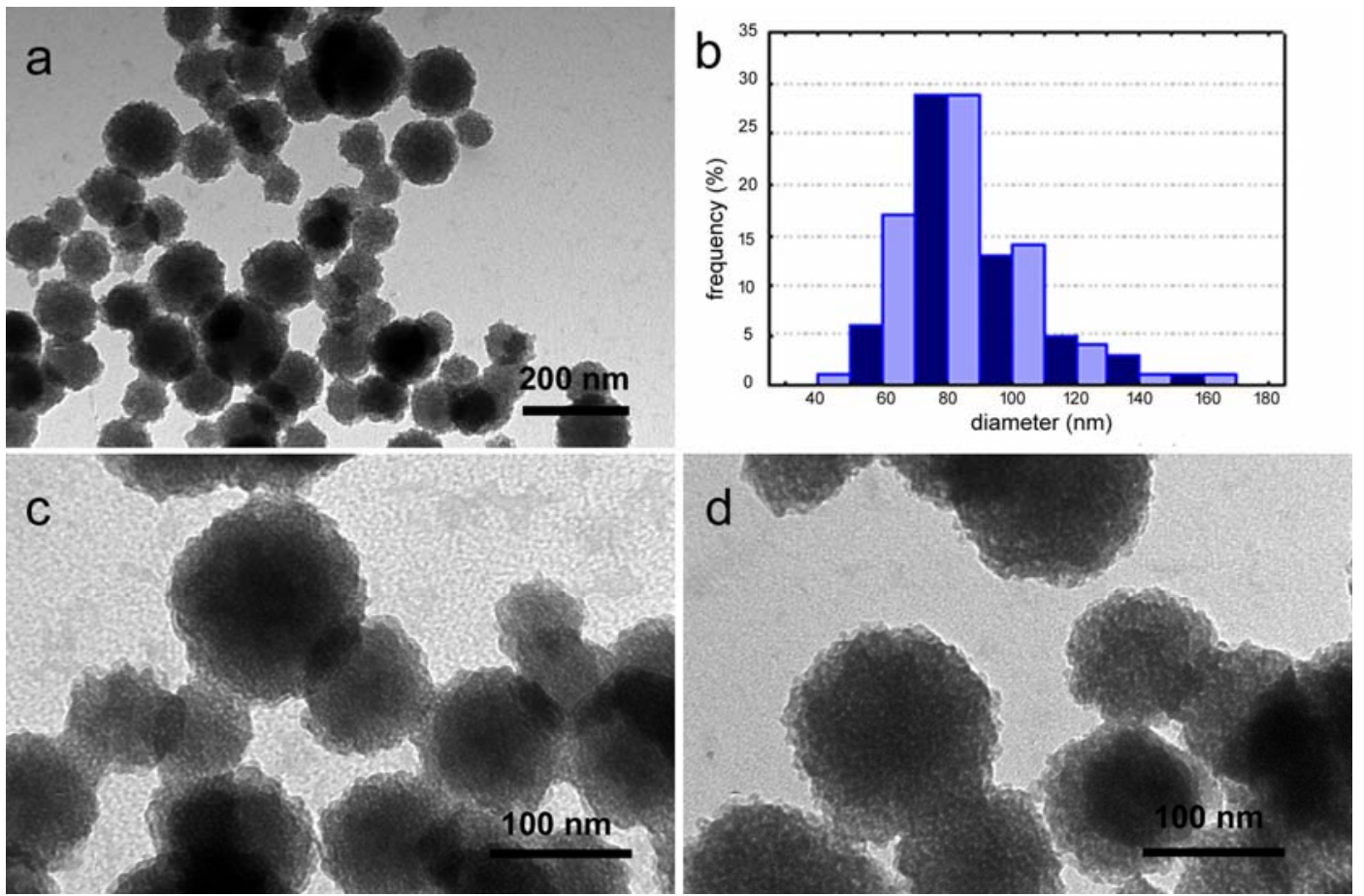

Figure 1. Transmission electron microscopy (TEM) images of as-prepared mesoporous bioactive glass nanospheres (nMBG) (a,c) with relative size distribution (b); and of AL100 (d).

Table 1. Specific surface areas, pore volumes, and alendronate (AL) content of samples obtained on increasing concentrations of AL in solution.

\begin{tabular}{cccc}
\hline Sample & Specific Surface Area $\left(\mathbf{m}^{2} / \mathbf{g}\right)$ & Pore Volume $\left(\mathrm{cm}^{3} / \mathbf{g}\right)$ & AL Content $(\mathbf{w t} \%)$ \\
\hline nMBG & $528.4 \pm 0.9$ & $0.63 \pm 0.02$ & - \\
AL25 & $327.3 \pm 0.3$ & $0.65 \pm 0.02$ & $4.7 \pm 0.2$ \\
AL50 & $349.5 \pm 0.4$ & $0.36 \pm 0.01$ & $9.0 \pm 0.4$ \\
AL100 & $165.3 \pm 0.3$ & $0.44 \pm 0.01$ & $17.0 \pm 0.9$ \\
\hline
\end{tabular}

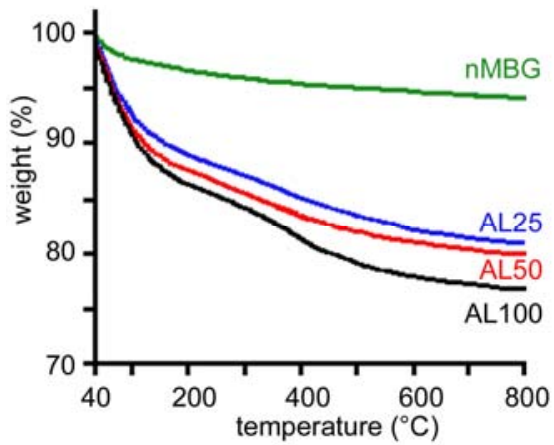

Figure 2. Thermogravimetric plots of the samples with different alendronate content.

TEM images show that the morphology of the nanospheres is not significantly modified by AL loading (Figure 1d). However, AL incorporation provokes a significant decrease of the surface area and of the mean pore volume on increasing the bisphosphonate content up to about $17 \%$ (Table 1), suggesting a preferential interaction of the bisphosphonate with calcium ions on the pore surface. 


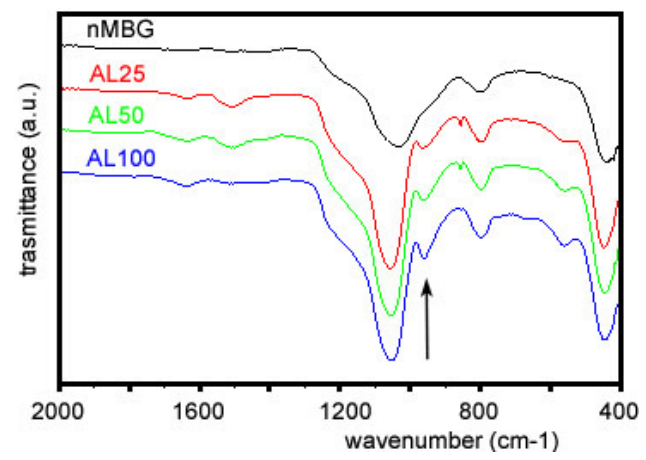

Figure 3. Fourier transform infrared spectroscopy (FT-IR) adsorption spectra of of the samples with different alendronate content. The band indicated by the arrow can be attributed to alendronate.

In vitro mineralization, as well in vitro tests with osteoblast-like cells, were performed on disk shaped samples, which were obtained by pressing the powders into cylindrical molds. The surfaces of the disk-shaped samples are quite smooth, although they allow the nanospheres to be distinguished, as shown in the AFM image reported in Figure 4 . The roughness parameters, $R_{\mathrm{a}}, R_{\mathrm{q}}$, and $R_{\max }$, do not vary significantly with composition and exhibit mean values of $R_{\mathrm{a}}=53.60 \pm 3 \mathrm{~nm}$, $R_{\mathrm{q}}=80.56 \pm 9 \mathrm{~nm}$, and $R_{\max }=533.08 \pm 70 \mathrm{~nm}$. Accordingly, the values of contact angles are about $20^{\circ}$ and do not vary as a function of AL content, thus indicating that all the samples display hydrophilic behavior. Slight differences can be appreciated in the time taken by the water droplet to completely spread on the sample surface, which range from $0.2 \mathrm{~s}$ for nMBG to $0.6 \mathrm{~s}$ for AL50 and to $1 \mathrm{~s}$ for AL100. This could be justified by the decreasing pore volume in these materials.

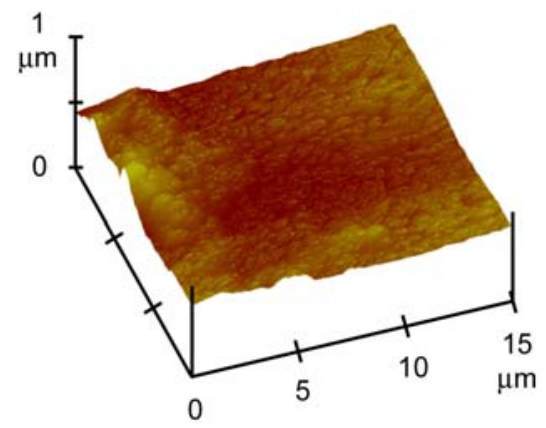

Figure 4. Atomic force microscopy (AFM) image of the surface of the nMBG disk-shaped sample.

Thanks to the presence of calcium, both $\mathrm{nMBG}$ and AL-loaded nanospheres promote mineralization from SBF. SEM images of the samples after immersion in SBF for one week show that the surface of the different disks are completely covered with apatite spheroids [30], which exhibit a mean diameter of about $500 \mathrm{~nm}$ (Figure 5).

Energy dispersive X-ray analysis (EDX) shows that nMBG exhibit only $\mathrm{Ca}$ and $\mathrm{Si}$ signals, whereas a distinct $P$ signal can be detected after immersion in SBF. (Figure 5). No significant difference, in terms of morphology and composition, was appreciated between the deposits laid down on nMBG and AL-loaded nanospheres. 

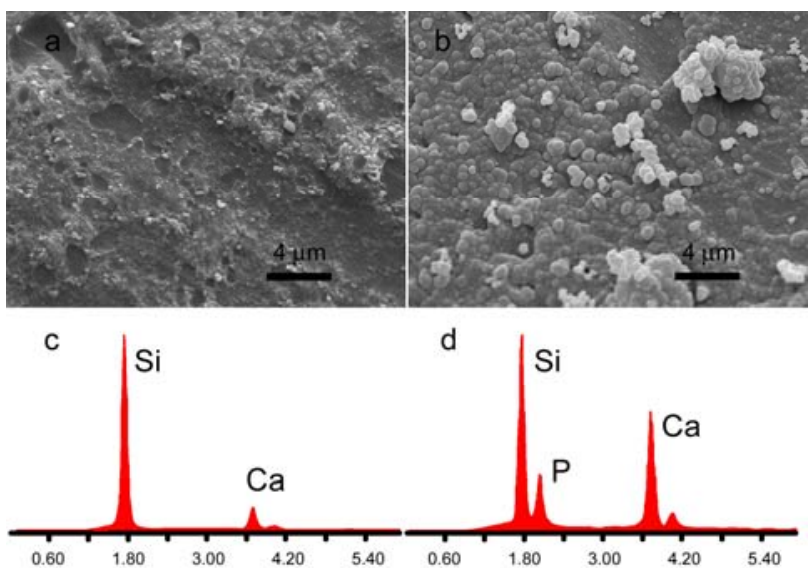

Figure 5. Scanning electron microscopy (SEM) images of disk-shaped samples surface as-prepared (a) and after immersion in simulated body fluid solution (SBF) for 1 week (b); Energy dispersive X-ray analyses (EDX) of disk-shaped sample surface as-prepared (c) and after immersion in SBF for 1 week (d).

\subsection{In vitro Cell Analysis}

The first part of the biological study was focused on the investigation of the proposed systems as potential inhibitors of osteosarcoma cell viability. MG63 cells were directly seeded on the upper surface of the samples and, as shown in Figure 6A-D, a consistent difference in cell density was seen starting from day 3 between the nMBG group and the others groups. A further demonstration of this cell viability reduction was seen with the MTT test (Figure 6E). It is remarkable that substantial decrease in cell proliferation ( $\approx 50 \%$ with respect to the nMBG group) was detected at day 3 and day 7 without any statistical differences among the group. These results proved the direct effect of our system on decreasing tumor cell viability even at the lower concentration of alendronate, in agreement with the suggested direct role of BPs in cancer treatment [38,39]. Even if the mechanisms of anticancer action of BPs are not completely known, it has been shown that BPs can exert direct cytostatic and antiproliferative effects against a variety of tumor cells including osteosarcoma, and metastasis in some tumors such as breast cancer, renal cell carcinoma, and prostate cancer [40-42].
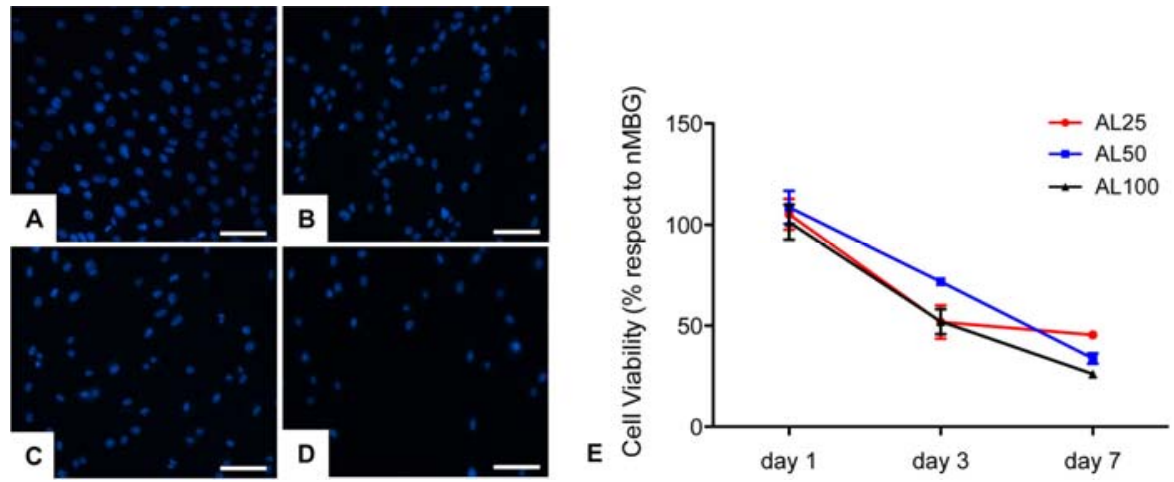

Figure 6. Fluorescence images of cell nuclei of MG63 cells seeded on the samples: (A) nMBG; (B) AL25; (C) AL50; and (D) AL100. Scale bars $100 \mu \mathrm{m}$. Cell viability (\% with respect to nMBG) till day 7 (E).

A further aspect of the proposed systems is related to the inhibition of OCLs' activity. Due to the fact that the aggressiveness of OS is associated with an increase of OCLs' activity, osteoclast-targeted therapy is potentially an important avenue for addressing the progression of local and systemic OS disease. The RAW 264.7 cells were seeded in 24-well inserts, in the presence of sRANKL to induce osteoclastogenesis, and the samples with different amounts of alendronate were placed one per well 
in the 24-well plate. The presence of large and multinucleated cells showing a typical apico-basal actin-rich structure in $n M B G$ group indicate that cells were grown regularly during the experiments and confirm the OCLs' differentiation model (Figure 7) [43,44]. TRAP is physiologically highly expressed by active OCLs, and the results of this study show a strong, alendronate dose-dependent, reduction of TRAP activity (Figure 7B). In detail, AL100 shows the strongest TRAP activity reduction with respect to the nMBG group (TRAP activity $<10 \%$ ) at both time points with statistical differences versus AL25 $(p<0.001$ at day 3 and day 7) and versus AL50 ( $p<0.5$ at day 7). Furthermore, TRAP activity of AL50 results significantly reduced with respect to the nMBG group (TRAP activity $<40 \%$ ), showing statistical differences with AL25 at both time points ( $p<0.01$ at day 3 and $p<0.05$ at day 7). It is remarkable that even with the lowest amount of alendronate, AL25, there is a notable TRAP activity reduction proving that the proposed systems are promising drug delivery biomaterials.
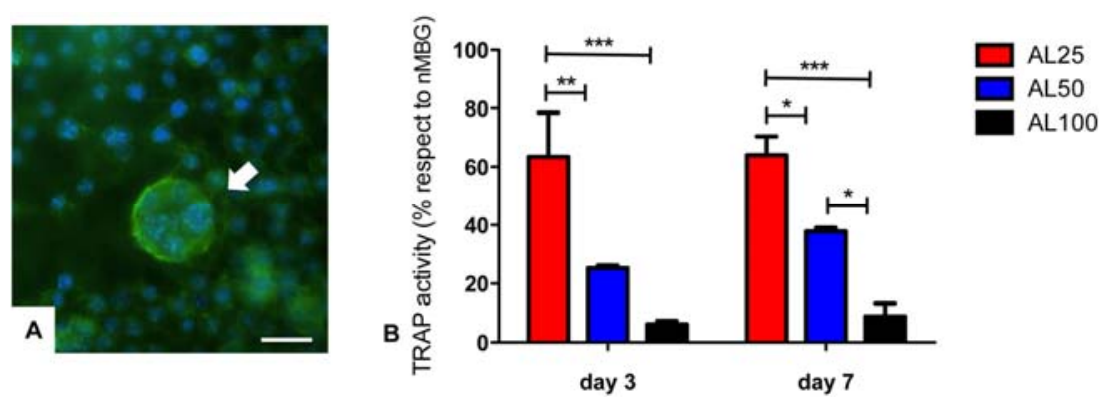

Figure 7. (A) sRANKL-treated RAW 264.7 cells of nMBG, arrow indicates a multinucleated osteoclast (OCLs) (actin in green, cell nuclei in blue). Scale bar $50 \mu \mathrm{m}$; (B) Tartrate resistant acid phosphatase (TRAP) activity shown as $\%$ with respect to nMBG used as control. ${ }^{*} p \leqslant 0.05 ;{ }^{* *} p \leqslant 0.01 ;{ }^{* * *} p \leqslant 0.001$.

Moreover, in order to confirm the strong OCLs' inhibition due to the presence of functionalized biomaterials, mRNA levels of Oscar and CtsK, typical osteoclastogenesis markers, were measured. In detail, Oscar is an OCLs' associated receptor, its expression follows TRAP during osteoclasts differentiation [45]; CtsK is highly and quite selectively expressed in osteoclasts and it is a key protease in degradation of bone matrix molecules [46]. The results show a down-regulation of CtsK in the groups with alendronate compared to the $\mathrm{nMBG}$ group used as control without statistical differences among the AL groups (Figure 8). Interestingly, Oscar mRNA expression is completely inhibited by the presence of alendronate, in factthe mRNA level is undetectable (Figure 8).

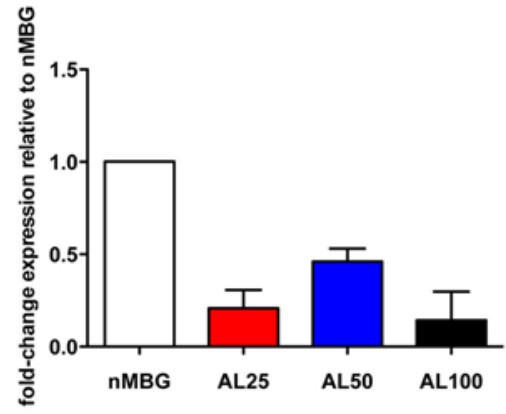

(a)

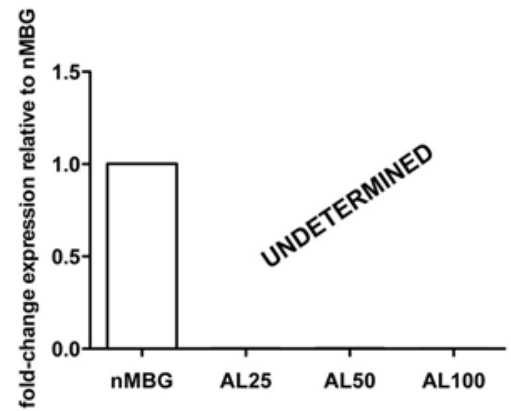

(b)

Figure 8. OCLs gene expression analysis. Relative quantification $\left(2^{-\Delta \Delta C}\right.$ ) of gene expression after 7 days of OCLs cultured in direct contact with all the tested samples. Average and standard error of the technical triplicate of CtsK (a) and Oscar (b), with respect to the expression of the cells of nMBG, are indicated. 


\section{Conclusions}

The approach developed in this study allows mesoporous bioglass nanospheres to be loaded with increasing amounts of alendronate up to about $17 \mathrm{wt} \%$ and yields materials where the ability to promote mineralization of the nanospheres is coupled with the antiresorptive and anticancer properties of alendronate. The results of in vitro tests prove that the proposed multifunctional system is a promising platform for controlled regulation of osteosarcoma cells and osteoclast activity, providing a new tool for OS treatment.

Acknowledgments: The authors gratefully acknowledge Fondazione del Monte di Bologna e Ravenna (Prot. No. 434 bis/ 2015 del 20 Luglio 2015, “Nanoparticelle di silice porosa come vettori di rilascio controllato di farmaci in pazienti osteoporotici"). The authors acknowledge Samuele M. Dozio for technical help in performing part of the in vitro study.

Author Contributions: E.B., C.C. and A.B. conceived and designed the experiments; E.B., S.P., F.A., M.M., K.R. performed the experiments; E.B., S.P. analyzed the data; A.T., C.C., A.B. contributed materials and analysis tools; E.B., S.P., C.C., A.B. wrote the paper.

Conflicts of Interest: The authors declare no conflict of interest.

\section{References}

1. World Health Organization. Classification of Tumours of Soft Tissue and Bone, 4th ed.; International Agency for Research on Cancer: Lyon, France, 2013; pp. 281-295.

2. Kansara, M.; Teng, M.W.; Smyth, M.J.; Thomas, D.M. Translational biology of osteosarcoma. Nat. Rev. Cancer 2014, 14, 722-735. [CrossRef] [PubMed]

3. Avnet, S.; Longhi, A.; Salerno, M.; Halleen, J.M.; Perut, F.; Granchi, D.; Ferrari, S.; Bertoni, F.; Giunti, A.; Baldini, N. Increased osteoclast activity is associated with aggressiveness of osteosarcoma. Int. J. Oncol. 2008, 33, 1231-1238. [CrossRef] [PubMed]

4. Akiyama, T.; Dass, C.R.; Choong, P.F.M. Novel therapeutic strategy for osteosarcoma targeting osteoclast differentiation, bone-resorbing activity, and apoptosis pathway. Mol. Cancer Ther. 2008, 7, 3461-3469. [CrossRef] [PubMed]

5. $\quad$ Russell, R.G.G.; Watts, N.B.; Ebetino, F.H.; Rogers, M.J. Mechanisms of action of bisphosphonates: Similarities and differences and their potential influence on clinical efficacy. Osteoporos. Int. 2008, 19, 733-759. [CrossRef] [PubMed]

6. Fleisch, H. Bisphosphonates in Bone Disease, from the Laboratory to the Patient; Academic Press: San Diego, CA, USA, 2000.

7. Martin, T.J.; Grill, V. Bisphosphonates-mechanisms of action. Aust. Prescr. 2000, 23, 130-132.

8. Nancollas, G.H.; Tang, R.; Phipps, R.J.; Henneman, Z.; Gulde, S.; Wu, W.; Mangood, A.; Russell, R.G.G.; Ebetino, F.H. Novel insights into actions of bisphosphonates on bone: Differences in interactions with hydroxyapatite. Bone 2006, 38, 617-627. [CrossRef] [PubMed]

9. Russell, R.G.G. Determinants of structure-function relationships among bisphosphonates. Bone 2007, 40, S21-S25. [CrossRef]

10. Eriksen, E.F; Diez-Perez, A.; Boonen, S. Update on long-term treatment with bisphosphonates for postmenopausal osteoporosis: A systematic review. Bone 2014, 58, 126-135. [CrossRef] [PubMed]

11. Fazil, M.; Baboota, S.; Sahni, J.K.; Ameeduzzafar; Ali, J. Bisphosphonates: Therapeutics potential and recent advances in drug delivery. Drug Deliv. 2015, 22, 1-9. [CrossRef] [PubMed]

12. Favia, G.; Pilolli, G.P.; Maiorano, E. Histologic and histomorphometric features of bisphosphonate-related osteonecrosis of the jaws: An analysis of 31 cases with confocal laser scanning microscopy. Bone 2009, 45, 406-413. [CrossRef] [PubMed]

13. Rizzoli, R.; Åkesson, K.; Bouxsein, M.; Kanis, J.A.; Napoli, N.; Papapoulos, S.; Reginster, J.Y.; Cooper, C. Subtrochanteric fractures after long-term treatment with bisphosphonates: A European society on clinical and economic aspects of osteoporosis and osteoarthritis, and international osteoporosis foundation working group report. Osteoporos. Int. 2011, 22, 373-390. [CrossRef] [PubMed]

14. Verron, E.; Bouler, J.M. Is bisphosphonate therapy compromised by the emergence of adverse bone disorders? Drug Discov. Today 2014, 19, 312-319. [CrossRef] [PubMed] 
15. Josse, S.; Faucheux, C.; Soueidan, A.; Grimandi, G.; Massiot, D.; Alonso, B.; Janvier, P.; Laïb, S.; Pilet, P.; Gauthier, O.; et al. Novel biomaterials for bisphosphonate delivery. Biomaterials 2005, 26, 2073-2080. [CrossRef] [PubMed]

16. Roussiere, H.; Montavon, G.; Laib, S.; Janvier, P.; Alonso, B.; Fayon, F.; Petit, M.; Massiot, D.; Bouler, J.M.; Bujoli, B. Hybrid materials applied to biotechnologies: Coating of calcium phosphates for the design of implants active against bone resorption disorders. J. Mater. Chem. 2005, 15, 3869-3875. [CrossRef]

17. Peter, B.; Pioletti, D.P.; Laïb, S.; Bujoli, B.; Pilet, P.; Janvier, P.; Guicheux, J.; Zambelli, P.Y.; Bouler, J.M.; Gauthier, O. Calcium phosphate drug delivery system: Influence of local zoledronate release on bone implant osteointegration. Bone 2005, 36, 52-60. [CrossRef] [PubMed]

18. Verron, E.; Gauthier, O.; Janvier, P.; Pilet, P.; Lesoeur, J.; Bujoli, B.; Guicheux, J.; Bouler, J.M. In vivo bone augmentation in an osteoporotic environment using bisphosphonate-loaded calcium deficient apatite. Biomaterials 2010, 31, 7776-7784. [CrossRef] [PubMed]

19. Seshima, H.; Yoshinari, M.; Takemoto, S.; Hattori, M.; Kawada, E.; Inoue, T.; Oda, Y. Control of bisphosphonate release using hydroxyapatite granules. J. Biomed. Mater. Res. B 2006, 78, 215-221. [CrossRef] [PubMed]

20. Panzavolta, S.; Torricelli, P.; Bracci, B.; Fini, M.; Bigi, A. Functionalization of biomimetic calcium phosphate bone cements with alendronate. J. Inorg. Biochem. 2010, 104, 1099-1106. [CrossRef] [PubMed]

21. Boanini, E.; Torricelli, P.; Gazzano, M.; Fini, M.; Bigi, A. The effect of zoledronate-hydroxyapatite nanocomposites on osteoclasts and osteoblast-like cells in vitro. Biomaterials 2012, 33, 722-730. [CrossRef] [PubMed]

22. Boanini, E.; Torricelli, P.; Gazzano, M.; Fini, M.; Bigi, A. Crystalline calcium alendronate obtained by octacalcium phosphate digestion: A new chance for local treatment of bone loss diseases? Adv. Mater. 2013, 25, 4605-4611. [CrossRef] [PubMed]

23. Boanini, E.; Torricelli, P.; Gazzano, M.; Della Bella, E.; Fini, M.; Bigi, A. Combined effect of strontium and zoledronate on hydroxyapatite structure and bone cell responses. Biomaterials 2014, 35, 5619-5626. [CrossRef] [PubMed]

24. Balas, F.; Manzano, M.; Horcajada, P.; Vallet-Regi, M. Confinement and controlled release of bisphosphonates on ordered mesoporous silica-based materials. J. Am. Chem. Soc. 2006, 128, 8116-8117. [CrossRef] [PubMed]

25. Vallet-Regi, M. Revisiting ceramics for medical applications. Dalton Trans. 2006, 44, 5211-5220. [CrossRef] [PubMed]

26. López-Noriega, A.; Arcos, D.; Izquierdo-Barba, I.; Sakamoto, Y.; Terasaki, O.; Vallet-Regí, M. Ordered mesoporous bioactive glasses for bone tissue regeneration. J. Mater. Chem. 2006, 18, 3137-3144. [CrossRef]

27. Xynos, I.D.; Edgar, A.J.; Buttery, L.D.; Hench, L.L.; Polak, J.M. Ionic products of bioactive glass dissolution increase proliferation of human osteoblasts and induce insulinlike growth factor II mRNA expression and protein synthesis. Biochem. Biophys. Res. Commun. 2000, 276, 461-465. [CrossRef] [PubMed]

28. Wu, C.; Fanb, W.; Chang, J. Functional mesoporous bioactive glass nanospheres: Synthesis, high loading efficiency, controllable delivery of doxorubicin and inhibitory effect on bone cancer cells. J. Mater. Chem. B 2013, 1, 2710-2718. [CrossRef]

29. Kuljanin, J.; Janković, I.; Nedeljković, J.; Prstojević, D.; Marinković, V. Spectrophotometric determination of alendronate in pharmaceutical formulations via complex formation with Fe(III) ions. J. Pharm. Biomed. Anal. 2002, 28, 1215-1220. [CrossRef]

30. Bigi, A.; Boanini, E.; Bracci, B.; Facchini, A.; Panzavolta, S.; Segatti, F.; Sturba, L. Nanocrystalline hydroxyapatite coatings on titanium: A new fast biomimetic method. Biomaterials 2005, 26, 4085-4089. [CrossRef] [PubMed]

31. Collin-Osdoby, P.; Yu, X.; Zheng, H.; Osdoby, P. RANKL-mediated osteoclast formation from murine RAW 264.7 cells. Methods Mol. Med. 2003, 80, 153-166. [PubMed]

32. Tseng, F.J.; Chia, W.T.; Shyu, J.F.; Gou, G.H.; Sytwu, H.K.; Hsia, C.W.; Tseng, M.J.; Pan, R.Y. Interactomics profiling of the negative regulatory function of carbon monoxide on RANKL-treated RAW 264.7 cells during osteoclastogenesis. BMC Syst. Biol. 2014, 8, 57. [CrossRef] [PubMed]

33. Liu, Y.; Peterson, D.A.; Kimura, H.; Schubert, D. Mechanism of cellular 3-(4,5-dimethylthiazol-2-yl)2,5-diphenyltetrazolium bromide (MTT) reduction. J. Neurochem. 1997, 69, 581-593. [CrossRef] [PubMed]

34. Faulstich, H.; Zobeley, S.; Rinnerthaler, G.; Small, J.V. Fluorescent phallotoxins as probes for filamentous actin. J. Muscle Res. Cell Motil. 1988, 5, 370-383. [CrossRef] 
35. Webster, T.J.; Ergun, C.; Doremus, R.H.; Siegel, R.W.; Bizios, R. Enhanced osteoclast-like cell functions on nanophase ceramics. Biomaterials 2001, 22, 1327-1333. [CrossRef]

36. Livak, K.J.; Schmittgen, T.D. Analysis of relative gene expression data using real-time quantitative PCR and the $2^{-\Delta \Delta C}$ T method. Methods 2001, 25, 402-408. [CrossRef] [PubMed]

37. Silverstein, R.M.; Webster, F.X.; Kiemle, D.J.; Bryce, D.L. Spectrometric Identification of Organic Compounds, 8th ed.; John Wiley \& Sons: Hoboken, NJ, USA, 2015; pp. 106-107.

38. Cheng, Y.Y.; Huang, L.; Lee, K.M.; Li, K.; Kumta, S.M. Alendronate regulates cell invasion and MMP-2 secretion in human osteosarcoma cell lines. Pediatr. Blood Cancer 2004, 42, 410-415. [CrossRef] [PubMed]

39. Silvina Molinuevo, M.; Bruzzone, L.; Cortizo, A.M. Alendronate induces anti-migratory effects and inhibition of neutral phosphatases in UMR106 osteosarcoma cells. Eur. J. Pharmacol. 2007, 562, 28-33. [CrossRef] [PubMed]

40. Kubista, B.; Trieb, K.; Sevelda, F.; Toma, C.; Arrich, F.; Heffeter, P.; Elbling, L.; Sutterluty, H.; Scotlandi, K.; Kotz, R.; et al. Anticancer effects of zoledronic acid against human osteosarcoma cells. J. Orthop. Res. 2006, 24, 1145-1152. [CrossRef] [PubMed]

41. Lipton, A. Toward new horizons: The future of bisphosphonate therapy. Oncologist 2004, 9, 38-47. [CrossRef] [PubMed]

42. Virtanen, S.S.; Väänänen, H.K.; Härkönen, P.L.; Lakkakorpi, P.T. Alendronate inhibits invasion of PC-3 prostate cancer cells by affecting the mevalonate pathway. Cancer Res. 2002, 62, 2708-2714. [PubMed]

43. Hou, J.M.; Xue, Y.; Lin, Q.M. Bovine lactoferrin improves bone mass and microstructure in ovariectomized rats via OPG/RANKL/RANK pathway. Acta Pharmacol. Sin. 2012, 33, 1277-1284. [CrossRef] [PubMed]

44. Vaananen, H.K.; Zhao, H.; Mulari, M.; Halleen, J.M. The cell biology of osteoclast function. J. Cell Sci. 2000, 113, 377-381. [PubMed]

45. Kim, N.; Takami, M.; Rho, J.; Josien, R.; Choi, Y. A novel member of the leukocyte receptor complex regulates osteoclast differentiation. J. Exp. Med. 2002, 195, 201-209. [CrossRef] [PubMed]

46. Kiviranta, R.; Morko, J.; Alatalo, S.L.; NicAmhlaoibh, R.; Risteli, J.; Laitala-Leinonen, T.; Vuorio, E. Impaired bone resorption in cathepsin K-deficient mice is partially compensated for by enhanced osteoclastogenesis and increased expression of other proteases via an increased RANKL/OPG ratio. Bone 2005, 36, 159-172. [CrossRef] [PubMed]

(C) 2016 by the authors; licensee MDPI, Basel, Switzerland. This article is an open access article distributed under the terms and conditions of the Creative Commons by Attribution (CC-BY) license (http:/ / creativecommons.org/licenses/by/4.0/). 